\title{
Political Will, Political Skill, Network Resources and Personal Reputation: A Serial Two-Mediator Model
}

\author{
Orkun Demirbağ ${ }^{1}$, Hale Cide Demir ${ }^{2}$, Uğur Yozgat ${ }^{3}$
}

Submitted: 17.07.20. Accepted: 11.09.20

\section{Abstract}

Purpose: Although social capital and positive reputation in organizations are essential for career success, there is a limited perspective in the literature on the political characteristics (motivation and ability) that enable one to acquire and develop the two elements. This study seeks to investigate the sequential role of political skill and network resources as serial mediators of the political will-personal reputation relationship.

Methodology: In total, what provided data for the study were 457 sales executives from 13 different sectors in the cities of İstanbul, Kocaeli, and Bursa, which is an economically leading region of western Turkey. Executives rated their political will, political skill network resources, and personal reputation. Based on the complementary theories of political influence, social network, and signaling, we analyzed the relationships between constructs with structural equation modeling.

Findings: Political skill mediated the relationship between political will and network resources, network resources mediated the relationship between political skill and personal reputation, while political skill and network resources sequentially mediated the relationship between political will and personal reputation.

Implications: The data were collected from a single source.

Practical Implications: Political will, political skill training, and social networks may help individuals manage their personal reputation at work, thus benefiting their careers.

Originality/Value: This is one of the first studies to sequentially investigate how individuals' characteristics (motivation and ability) develop their social network and personal reputation at work. Moreover, theories of political influence, social capital, and signaling were jointly used for the first time ever.

Keywords: political will, political skill, network resources, personal reputation.

JEL: M12, M19

\footnotetext{
1 Faculty of Economics and Administrative Sciences, Gumushane University, Department of Business Adminstration, Baglarbasi Mah. 29100, Gumushane, Turkey, e-mail: orkundemirbag@gumushane.edu.tr, https://orcid.org/0000-0001-9889-3401.

2 Department of Business Administration, Kadir Has University, Kadir Has Cad. Cibali 34083 İstanbul, Turkey, e-mail: halecidedemir@gmail. com, https://orcid.org/0000-0002-1876-504X.

3 Faculty of Economics and Administrative Sciences, Nisantasi University, Department of Management Information Systems, Maslak Mah. 34481742, Istanbul, Turkey, e-mail: ugur.yozgat@nisantasi.edu.tr, https://orcid.org/0000-0001-9893-3551.
} 


\section{Introduction}

From the political perspective, research on both organizational and career theories is highly prevalent in the last forty years (Pfeffer, 1981; Mintzberg, 1983; Inkson, 2004; Vigoda-Gadot and Drory, 2016). Although there is a large amount of empirical research in the literature in the areas of influence and impression management (Lee et al., 2017), perceptions of organizational politics (Hochwarter et al., 2020), and political skill (Munyon et al., 2015), scholars only recently empirically measure the concept of political will (Kapoutsis et al., 2017), which is one of the critical elements of organizational politics, and it is a widely and conceptually mentioned concept in the literature. Despite it having no such broad historical background as political skill in explaining the theory of political influence, political will is expected to have an essential contribution to it. The political influence theory assumes that politically skilled individuals who can understand others have personal and organizational advantages (Ferris et al., 2007). Granger et al. (2020) state that the theory not only integrates political knowledge but also provides a useful framework for distinguishing political structures related to political skill, political will, and political savvy. In this context, the related theory links under its umbrella social capital theory (Bolender et al., 2015), firm's behavioral theory and network perspectives (Wei et al., 2012), guanxi (Wei et al., 2010), LMX and social change theories (Brouer, Teradway, and Ferris, 2013), thus joining the study of working relations with political skill within the context of social networks (Harris, Maher, and Ferris, 2016). However, as the motivating factor in the process of creating political knowledge (Yang et al., 2019), political will is considered by many to be the "missing part" in the theory of political influence. Whereas political skill refers to an ability that allows employees to take advantage of ambiguous situations, political will is closely linked to one's motivation to do so (Hochwarter et al., 2020, p. 21). Harris et al. (2016) state that the theory of political influence provides a context in which political skill and political will are addressed together, and which has the potential to make a significant contribution to much future research by extending political characteristics in the field of organizational politics research (Ferris et al., 2019). This study is critical both in terms of revealing its relationship with the social capital theory under the umbrella of "political influence" and in the use of political will, which is thought to be a significant deficiency in the process of creating political knowledge. It is believed that investigating whether this is the trigger of "social network" will make an essential contribution to the literature.

According to social capital theory, the relationship networks between individuals are determined by access to information, influence, and changes in organizations (Brass, 2001; Burt, 1992; Coleman, 1988), and this concept is proposed as an opinion based 
on the development of relationship networks of influential individuals within the social structure (Thompson, 2005). Social capital can have several positive results of strategic importance for individuals, such as higher compensation and a more successful career (Bozionelos, 2015; Richardson and Kelliher, 2015), knowledge transfers and innovation (Maurer, Bartsch, and Ebers, 2011), but also performance improvement (Moran, 2005). On the other hand, many studies consider the dark side of social capital (Portes, 1998; Beyerlein and Hipp, 2005; Schulman and Anderson, 1999), which consists of negative results (Edelman et al., 2004; Kwon and Adler, 2014), such as barriers to learning, group-thinking, negative information, decision-making quality, and their outcomes (Staw, 1981; Pillai et al., 2017; Wang, McNally, and Lenihan, 2018).

Network resources are the most important elements of social capital in an organization with mentorship (Seibert, Kraemer, and Liden, 2001; Bozionelos, 2003; Bozionelos and Wang, 2006; Wei et al., 2012). Mentoring is described as an overly intense relationship between a stronger and experienced mentor and a focus person in an organization (Phillips-Jones, 1983; Kram, 1985), whereas network resources are mentioned as the sum of the individual's interpersonal ties and networks, apart from basic mentoring relationships (Burt, 1992). Individuals with political characteristics in an organization develop their social capital both by protecting their existing networks and by building new networks (Wei et al., 2010). People who want to develop network resources use upward influencing tactics, such as solution generation, bargaining, assertiveness, resorting to higher autonomy, coalitions, and friendship, considering the personal style of the person they want to network with (Kipnis and Schmidt, 1982). The organization has three main ways of accessing network resources: 1) reliance on trustworthiness, confidence, and sincerity to regulate their behavior and behave in a way that earns the trust of people in an organization (Perrewe et al., 2000); 2) employee interpersonal influence viewed as an opportunity rather than a threat (Perrewe et al., 2000; Zellars, Perrewe, et al., 2008); and 3) network resources are fed from both weak ties and strong ties (Granovetter, 1973; Burt, 1992). Individuals in an organization acquire their network resources through their political abilities and develop their knowledge and understanding of relationships between the informal structure of the organization and the (tactical) activities of one's influence (Kilduff and Tsai, 2003). Therefore, employees will connect to their networks by making use of both existing and new networks, will switch to a central location (Ammeter et al., 2002; Jawahar et al., 2008; Perrewe et al., 2000), and turn their networks into an advantage (Granovetter, 1973). Furthermore, individuals with political characteristics through their networks-appear to be more valuable in their teams as they are well-positioned both inside and outside of an organization and provide resources for their departments (House, 1995). Although there are many benefits of networking (Forret and Dougherty, 2001; Bozioneles, 2003; 
Forret and Dougherty, 2004; Bozioneles and Wang, 2006; Breland et al., 2007; Wei et al., 2012), there are not many studies regarding the antecedents of networking sources in job engineering (Zhang, Zheng, and Wei, 2009), especially regarding the employees who trigger support for activities in the organization and who hold informal positions that control how people interact with each other (Kilduff and Tsai, 2003). Social network researchers assume that individual characteristics are influential in the development of networks (Douglas and Ammeter, 2004; Burt, 2005; Thompson, 2005; Ferris et al., 2007). The gained, developed, and effectively used individual networking resources (Bozioneles, 2003) are closely related to the individual's skills and characteristics. Why are some employees more successful compared to other employees in some cases, such as creating coalitions, forming networks, and access to information (Wei et al., 2012)? The vast majority of previous studies attributes the reason behind this case of success to demographic characteristics (Galaskiewicz and Shatin, 1981; Ibarra, 1993), individual characteristics (Bozioneles, 2003), and self-monitoring (Mehra, Kilduff, and Brass, 2001). However, the motivation that is used in helping networking resources emerge has not been sufficiently explained (Zhang et al., 2009; Wei et al., 2012), and this situation constitutes another research gap in the scholarship.

In the management literature, the concept of reputation always appears arbitrary, but the information regarding this concept remains in its infancy (Zinko, Gentry, and Laird, 2016). Over the last few years, the literature has gradually investigated why individuals and organizations would want to create a positive reputation (Zinko and Rubin, 2015; Ferris et al., 2014; Hall et al., 2009; Laird et al., 2008; Laird et al., 2013; Zinko, 2013; Zinko et al., 2012a). A positive reputation is grounded in signaling theory (Treadway et al., 2009, p. 556). Spence (1973) argues that the signal transmits information about individuals' actions, intentions, and abilities, which is revealed by how individuals create positive reputation in the process of developing it (Blickle et al., 2011). Furthermore, Ferris and Judge (1991) suggest that individuals may attempt to manipulate reputational signaling to their advantage through social and political influence efforts, so they interpret reputation as a deliberate effort to signal. Therefore, the signals sent to others to gain reputation have political meaning as they try to influence perceptions and meanings (Zinko et al., 2007). As the signaling theory suggests, employers seek a "fit" between executives and employees when making promotion decisions, because "fit" can be perceived as an indicator of organizational commitment and identity (Perrewe et al., 2007). Creating a positive image in the organization is routine behavior for managers who use their political skills in the organization (Huang, 2017). Thanks to this ability, the managers will spread the positive image that they adapt very well to the organization. However, limited research is available in the literature on motivation that prompts political skill (Kapoutsis et al., 2017). 
Therefore, motivated to become better in the organization, employees are more likely to influence their superiors by activating executive talents (Wright, 1979). As stated earlier, people with political will and political skill transmit signals that create a positive image to their targets by using proactive networking and situationally appropriate impact tactics (Blickle et al., 2011). Thus, these people can further improve their reputation (Perrewe et al., 2007). Besides, politically talented individuals are suggested to establish strong and positive relationships with their superiors to achieve rewards typically associated with positive personal reputation (Blickle et al., 2011). Beginning with this viewpoint, the current study aims to foreground political will and political skill as political antecedents of networking resources and their relationship with reputation, which is one of the indicators of career success.

\section{Conceptual Clarification and Hypothesis Development}

\section{Political Will and Personal Reputation}

Although political will is a concept proposed by Mintzberg (1983; 1985) almost four decades ago, it received relatively limited attention from researchers compared to its twin concept: political skill (Harris, Maher, and Ferris, 2016). Nevertheless, we notice that interest in political will literature is increasing with each day, which is one of the critical cornerstones of organizational politics literature. While political researchers deliberate about political will group - or society-level construct (Post, Raile, and Raile, 2010), organizational researchers seek to clarify the essence of political will as a phenomenon on an individual level (e.g. Treadway et al., 2005; Treadway, 2012; Kapoutsis et al., 2017). There are definitions of political will at the macro-level (e.g. Brinkerhoff, 2000; Post et al., 2010), but the description in the modernist meaning at the micro-level is realized by Treadway et al. $(2005 ; 2012)$. These authors describe individual-level political will in organizations as "the motivation to engage in strategic, goal-directed behavior that advances the personal agenda and objectives of the actor that inherently involves the risk of relational or reputational capital" (Treadway et al. 2012; p. 533). Political will is a component of organizational politics and political behavior; without it, no actor will have the desire to internally regulate politics in the workplace (Harris, Maher, and Ferris, 2016). Kapoutsis et al. (2017) - who improved an eight-item scale of self-rated political will - employs this conceptualization as a theoretical frame, which labels it as self-serving and benevolent (Treadway, 2012; Ferris et al., 2019). Self-serving is the motivation to act politically to protect sources and individual interests of the self, while benevolent is the motivation to behave politically for the benefit of other individuals, groups, or an organization (Harris, Maher, and Ferris, 2016, p. 20). 
Self-serving appertains to the personnel's need for achievement, power, and Machiavellianism, while the benevolent refers to the need for affiliation, organizational citizenship behavior, and voice behavior (Kapoutsis et al., 2017; Blickle, Schütte, and Wihler, 2018). In short, the theory of political will proposes that motivations conduct stimuli that affect persons to engage in influence behavior, and it is an essential motivational vein in specifying whether persons will abide by an opportunity (McAllister, Ellen III, and Ferris, 2018). Thereby, the main motive of politically wily individuals is the desire to gain positive reputation that can increase one's status (Tsui, 1984; Ferris et al., 2003; Kapoutsis et al., 2017), which illustrates the vital motivation mechanism of political behavior.

Personal reputation is one of the beneficial facts that we strive to achieve in both our individual (Zinko, Gentry, and Laird, 2016) and organizational life (Coombs and Holladay, 2002; Blombäck and Botero, 2013). While individuals can improve their reputation for many things in their daily lives, individuals need to develop their capacity to fulfill their work effectively and to collaborate and help others to gain reputation at work (Zinko et al., 2012b). Reputation is a perceptual identity formed from the collective perceptions of others, which is reflective of the complex combination of salient personal characteristics and accomplishments, demonstrated behavior, and intended images presented over a period of time, as observed directly and reported from secondary sources, which reduces ambiguity about expected future behavior (Zinko et al., 2007, p. 4). Some suggest that those who have a positive reputation at work can obtain better resources (Ferris et al., 2007), and this positive reputation has been linked to strength, career development, autonomy, and many other positive outcomes at work (Zinko et al., 2012b).

Today's competitive business environment has become increasingly crucial to the importance of political influence competence (political will and political skill), which facilitates interpersonal interactions, performance, and career development (Blickle et al., 2011). Individuals will also try to manipulate signals to gain reputation through their political influence efforts (Ferris and Judge, 1991). Hence, individuals achieve high-performance scores with the positive impact initiative signals that they send to their environment, which contribute to strengthening their reputation (Treadway, Campion, and Williams, 2017). In organizations, understanding individuals' political willingness by others significantly affects their reputation, which impacts hiring and performance appraisal decisions (Harris et al., 2016). However, the qualitative study conducted by Doldor et al. (2013) finds that engaging in politics is associated with a risk to reputation capital. The politics act as both a risky area and a contagious structure. As the level of individuals' willingness to participate in politics in their organization 
increases, they move away from their duties related to their jobs (Hochwarter et al., 2006). Individuals particularly high in political will might push too hard, risking too much, and seeing little or no return for it, which could also include the loss of personal reputation, social status, or even employment (Harris et al., 2016).

\section{Political Will, Political Skill, and Network Resources}

Researchers have long recognized that policies exist by nature of organizations (Pfeffer, 1981; Mintzberg, 1983; Ferris and Judge, 1991; Ferris and Hochwarter, 2012). In organizations - political arenas by nature - individuals should have "political will" and "political skill" to be effective (Mintzberg, 1983; Perrewe and Nelson, 2004). Political will is the motivation of individuals to risk personal and reputational capital by influencing others to create change in their organizations, either by paying regard to their self-interests or the benevolence of others. (Kapoutsis et al., 2017). Political skill is defined as "the ability to understand others at work effectively, and to use such knowledge to influence others to act in ways that enhance one's personal and/or organizational objectives" (Ahearn et al., 2004, p. 311). Individuals with high political skills can use this information to read, understand, influence people, collaborate, connect with others, and do all this sincerely (Ferris et al., 2005). Politically skilled individuals are enthusiastically adapted to different social situations (Ferris et al., 2005), and they can realize a personal style that allows them the ability to influence others (Blass and Ferris, 2007). People with high political skills not only know what, when, and where they should do in different social situations at work, but they simultaneously know precisely how to sincerely influence, by hiding any possible manipulation motive stemming from awareness, understanding, and greed (Ferris et al., 2001; Ammeter et al., 2002; Ahearn et al., 2004; Perrewe and Nelson, 2004). Political skill is a structure that consists of four dimensions: social astuteness, interpersonal influence, networking ability, and sincerity (Ferris et al., 2005; Ferris et al., 2007). Social astuteness is defined as "an actor's ability to diagnose and adapt to a variety of social situations." Interpersonal influence is the ability to appropriately select and utilize a wide variety of tactics that impact the cognitions and behaviors of others (Harris et al., 2016, p. 18). Network ability is the individual's ability to develop a vast network of people with whom s/he can develop beneficial alliances. Apparent sincerity refers to the individual's characteristic that makes him/her appear to be authentic, genuine, and open (Gill et al., 2014, p. 208). Moreover, political will represents the "motivational" side of political action, while political skill reveals the "ability" side.

The analysis of the organizational politics literature reveals that political skill is both a predictor of important work outcomes (e.g. performance, career, leadership, stress 
and strain, influence tactics, social network) and a mediator of key relationships at work (e.g. emotional intelligence-workplace outcomes, transformational leadership-work outcome; Ferris et al., 2019). In their literature review, Kranafeld, Blickle, and Meurs (in press) discuss the antecedents of political skill in five main dimensions and thirteen related sub-dimensions. Antecedents of political skill consist of self-monitoring, conscientiousness (Ferris et al., 2005), and emotion recognition ability (Momm et al., 2015), such as "perceptiveness," self-efficacy called "control" (Ferris et al., 2008), extraversion (Kolodinsky, Hochwarter, and Ferris, 2004; Ferris et al., 2008; Liu et al., 2007), positive affectivity (Kolodinsky et al., 2004), humility (Smith et al., 2009) called "affability;" receiving mentoring (Ferris et al., 2008), on-the-job learning (Oerder, Blickle, and Summers, 2014) called "developmental experience," proactive personality (Liu et al., 2007), self-motivation (Smith et al., 2009), dark personality (Templer, 2018), and political will called "active influence" (Kapoutsis et al., 2017). All these sub-indicators were put forward in previous studies as antecedents of political skill. Therefore, the literature makes it clear that "political will" from the active influence dimension is a precursor of political skill. Kapoutsis et al. (2017) state that the main factor that pushes individuals in organizations to strengthen their political skill to achieve their goals is political will. Political skill alone does not suffice to predict political behavior (Mintzberg, 1983). In an environment in which political uncertainty prevails - which provides an important opportunity for political action - individuals want to obtain higher opportunities by risking their social capital in order to increase their reputation with a high political will (Hochwarter et al., 2020). Without political will, political skill is immobile and does not work (Maher et al., 2018). Nevertheless, to date, political skill has been developed largely without the consideration of motivation (Kapoutsis et al., 2017).

Scholars focus on two inclusive research questions of social network research: (a) what are the causes of social networks?; (b) what are the results of social networks and the processes that affect them (Borgatti and Foster, 2003; Yang et al., 2019; Carpenter, Li, and Jiang, 2012)? Brass and Krackhardt (2012) suggest that political investigations of other network aspects - including structural holes - link strength, network closure, and ties to powerful others. Political perspective toward social network has recently become increasingly widespread in the literature (Zhang et al., 2009; Wei et al., 2012; Yang et al., 2019). While there are studies on the effect of demographic features (Galaskiewicz and Shatin, 1981; Ibarra, 1993; Klein et al., 2004) and self-monitoring (Mehra, Kilduff, and Brass, 2001) on social networks, there is limited research on how individual features affect individuals' social networks (Wei et al., 2012). Yang et al. (2019) state that as a result of the political process in the organization, we should understand the fundamentals of motivation to develop social networks of individuals. In that vein, they find that political will affects the social network. Political will is as important 
as political skill in understanding what strategies individuals will prefer in their organizations. Accordingly, political will can make it easier for individuals to obtain networks within the organization (Yang et al., 2019). Research shows that an individual is influenced by both political will (motivation) and political skill (ability) in obtaining social networks at work and outside (Treadway et al., 2010; Wei et al., 2012; Yang et al., 2019). People with higher levels of political skill will have no difficulty in obtaining resources and developing strong networks. However, when the political will of the same people is not high, they are unlikely to lead change or act against injustice. If these individuals' "political will" increases, individuals can gain social capital by mobilizing their political skill, and they can be likely to mobilize their environment to overcome various difficulties (Treadway et al., 2017). Hence, with political skill induced by political will, individuals can develop resource-rich and deep social networks (Ferris et al., 2007).

$\mathbf{H}_{1}$ : Political skill mediates the relationship between political will and social network in the organizations.

\section{Political Skill, Social Network, and Personal Reputation}

A social network consists of relationships and nodes of actors' ties (Ferris et al., 2009). It is used as a useful tool to identify and explain organizational events (Yang et al., 2019). Social networks are a powerful resource in modern organizations, so they should not be ignored (Eby, 1997; Higgins and Kram, 2001). In an organization, the networks of an individual are instrumental and expressive (Ibarra, 1993; Bozioneles, 2003). "Instrumental networks" involve the exchange of work-related resources created in the workplace. In contrast, "expressive networks" include exchanges of friendship and social support and are characterized by higher levels of closeness and trust than only instrumental ones (Ibarra, 1993, p. 59). People with critical networks in the workplace can both influence their progress decisions and be informed of strategic information within the organization, as they are at the center of the networks (Cannings and Montmarquette, 1991; Lin, 1999). Social networks are fed by our weak and strong ties (Granovetter, 1973; Burt, 1992), and they are open to being used by a politically skilled individual who can gain a specific advantageous position in the organization (Jafari et al., 2013; Huang, 2017). Network building is a social process, and political skill is the ability to effectively interpret and realize social ties, improve social situations and interpersonal quality (Ferris et al., 2005). Political skill is a crucial structure closely linked to social networking in business life (Huang, 2017). Politically skilled people can reach networks more easily with access, bridge, and wide-connection networks; hence, they activate both weak and strong ties (Wei et al., 2012). Politically skilled individuals 
know very well what kind of ties and things will they achieve thanks to their behavioral flexibility and situational variability (Ferris et al., 2000). Due to such features, these people can easily access more valuable information and resources by being in the right place at the right time (Perrewe et al., 2004; Ferris et al., 2005). Therefore, employees acquire networks thanks to their political skills and develop knowledge and understanding of an organization's informal structure and tactics that influence individuals (Kilduff and Tsai, 2003). Individuals can benefit from both existing and new networks (Jawahar et al., 2008) and turn their networks into an advantage (Granovetter, 1973). House (1995) states that people with high political skills are well-positioned through the networks they obtain and provide resources for their departments, thus being more valuable for their teams. Kilduff and Krackhardt (1994) find that even the perception of friendship with an effective person in an organization increases the individual's reputation. Accordingly, these people gradually increase their reputation capital in their environment thanks to their political skills. Politically skilled people tend to develop high-quality work relationships with their subordinates, superiors, and co-workers. Benefiting from the positive behavior associated with this high-quality business relationship, managers will respond to their subordinates with positive personal reputation and significant objective career outcomes (Blickle et al., 2011). Research shows that political skill is positively associated with the frequency of interaction with the manager (Shi et al., 2013) and the quality of work relationships and personal reputation (Laird et al., 2012; Munyon et al., 2015). Politically skilled individuals try to increase their positive personal reputations with the signals they send to their circles (Blickle et al., 2011). As a result of the signals sent to both expressive and instrumental networks, we notice that the reputation of these individuals is further reinforced (Portes, 1998; Lin, 1999).

$\mathbf{H}_{\mathbf{2}}$ : Network resources mediate the relationship between political skill and personal reputation in organizations.

In summary, people who think they can achieve some positive performance outcomes, opportunities for advancement, or rewards in their organizations act on their political aspirations. Individuals warned by their political will must mobilize their political skills to achieve these rewards and positively affect their environment. As a result of their political skills, they will both obtain relevant information from their networks and have strategic resources, and they will gain a positive reputation by their environment thanks to the signals they send to their environment. By integrating political influence theory, social network theory, and signaling theory, we can argue for the sequential nature of how individual characteristics such as political will and political skill influence social network and personal reputation. 
$\mathbf{H}_{3}$ : The relationships between political will and personal reputation will be serially mediated by political skill and, subsequently, network resources in the organization.

\section{Method}

\section{Procedure and Sample Characteristics}

Data were collected from 457 sales executives from 13 different sectors in the city of İstanbul, Kocaeli, and Bursa, which is an economically leading region of western Turkey. Holland's theory of business environment (1973) is considered one of the most influential work-based typologies in occupational psychology (McDaniel and Snell, 1999). According to Holland's theory, the business environment consists of six categories: realist, research, artistic, social, traditional, and enterprising. Enterprising job demands are characterized by such tasks as speaking to a group account, organizing meetings, leading discussions, leading a group, negotiating, advertising, propaganda efforts, selling, supervising, and persuading others (Bergmann and Eder, 1992). Enterprising jobs, businesses, promotion, advertising, sales, and management can be given as examples (Holland, 1973). The reason why sales managers form the research population is that sales management is a type of business with a high demand for jobs (Blickle et al., 2012), and people with political characteristics are more likely to choose social and enterprising careers (Kaplan, 2008). Thus, managers with such characteristics are more successful in the environment that provides opportunities to achieve interpersonal influences (Blickle et al., 2009). By using a purposive sampling method, the survey was sent to targeted participants through the sales executives of each company. Through a professional survey company, a total of 1300 e-mail invitations was sent out with a request to complete a web-based survey. The survey link with a randomized password to access was sent to targeted participants via their e-mail addresses. Out of 1,300 surveys electronically distributed between May 10 and September 10, 2019, 570 were returned, representing the response rate of $43.8 \%$. Ultimately, a total of 570 participants was selected, who provided 457 responses for the final data analysis. In the demographic profile, $36.1 \%$ of respondents were female, while $63.9 \%$ of respondents were male. Most participants had a bachelor's degree (60.8\%). A total of $30.2 \%$ were working as executives in the finance sector, $15.5 \%$ in the service sector, and $11.6 \%$ in fast-moving consumer goods. Forty-three percent of participants were working in chemistry, textile, electronics, construction, manufacturing, automobile, retail, and logistics sectors. Concerning the age of participants, 214 aged between 20-30 years, 112 between 
31-40 years, 96 between $41-50$, and 35 over 51 years. The years of experience ranged from five to 35 years, while the mean was 15 years.

\section{Measures}

Following Brislin's (1986) back-translation procedure, surveys were initially translated by two doctoral candidates - blind to the research objective - and later, the surveys were translated back from English to Turkish by another doctoral candidate. At this stage, a bilingual management professor was requested to compare whether there were differences in the original English survey and back-translation procedure. The questions were checked whether they could measure the relevant concept or not, and the face validity of the subject was tested after small corrections. Brislin's back-translation procedure has been widely used in many studies (e.g., Phalet and Poppe, 1997; Liao, Liu, and Loi, 2010; Joo et al., 2012 ; Wei et al., 2012; Shin et al., 2013). Moreover, all items in the survey were formed using a six-point Likert scale ranging from (1) definitely false and (6) definitely true. The survey consisted of several demographic variables, including scales measuring political will, political skill, network sources, and reputation.

Political will $(\alpha=, 0.88)$. An eight-item political will scale was developed by Kapoutsis et al. (2017). The measure consisted of self-serving and benevolent approaches. The Cronbach alpha value for the self-serving approach was 0.81 , while 0.86 for the benevolent approach.

Political skill $(\alpha=, 0.90)$. It was measured using political skill inventory by Ferris et al. (2005) and consisting of eighteen items. The measures comprise four dimensions of social astuteness, interpersonal influence, network ability, and apparent sincerity. The Cronbach alpha value for social astuteness was 0.76 ; 0.85 for network ability; 0.76 for interpersonal influence; and 0.80 for apparent sincerity.

Network Resources ( $\alpha=0.84)$. A six-item networking source scale developed by Bozenoleos (2003). The measure consisted of expressive and instrumental network resources. The Cronbach alpha value for expressive network resources was 0.83 and 0.81 for instrumental network resources.

Reputation ( $\alpha=0.91$ ). The reputation scale was developed by Hochwarter et al. (2007) and was a widely used career and performance dimension measuring twelve items. In the current study, the Cronbach alpha coefficients for career and performance scales were 0.87 and 0.87 , respectively. 


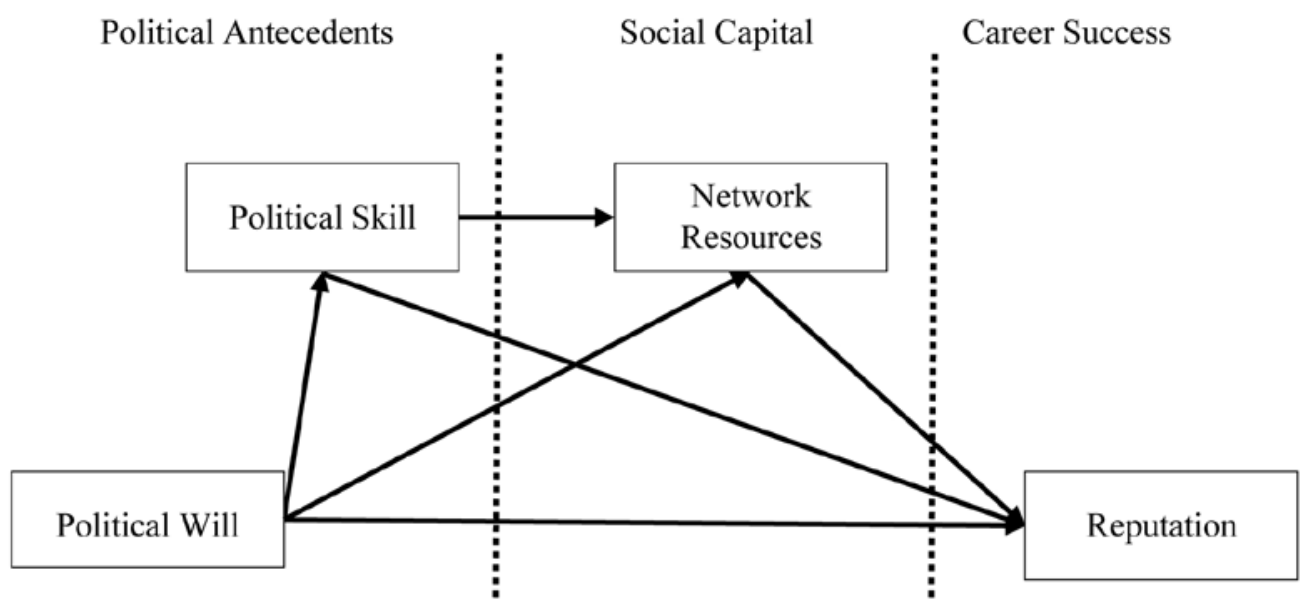

\section{Data Analysis}

Since the study investigates relationships among political will, political skill, network resources, and reputation, we carried out a common method variance bias to analyze whether there is common variance bias, confirmatory factor analysis (CFA), and to establish unidimensionality for each factor (Lu, Chang, and Chang, 2015); after that, we used SEM analysis to test the model. According to Klein (2010), with the bootstrap method used in structural equation modeling, models with both direct and indirect effects are tested at the same time, and the effects of measurement error are minimized. Otherwise, as an important advantage over alternative tests such as the Sobel test, bootstrapping contributes to the model to avoid Type 1 errors that may result from a non-normal distribution of the indirect effect (MacKinnon, Lockwood, and Williams, 2004). Our analysis comprised a two-step process. In the first stage, we computed the validity and reliability of the scale by using confirmatory factor analysis. After that, the hypothesis was tested using a structural equation model and was analyzed using Amos 23, a software package programming for the structural equation model. Although surveys collected from a single source are both cheap and easy in reaching a large number of participants, this method can cause common method variance bias (Podsakoff et al., 2003). Various analyses were performed to eliminate the common method variance (CMV) bias. According to Padsakoff (2003; 2012), it is possible to divide it into two groups as procedural and statistical obviation. Our study will demonstrate that there is no CMV statistically since the data is collected from a single source. In the first step, we committed to the confidentiality of participants' information in the cover letter of the survey. In the second step, we used Harman's single-factor test and checked if there is a CMV, since Harman's single-factor test should explain a single 
dominant factor (Andrews, Kacmar, and Valle, 2016; Zhai, Wang, and Weadon, 2017; Turulja and Bajgoric, 2019). For this test, a principal component analysis was performed using 44 items in the study. The analysis results without rotation demonstrated that there are ten factors with eigenvalues $>1$, which together clarified $66.2 \%$ of the total variance. The first factor clarified $27.5 \%$ of the variance. In the third step, we used a single-factor measurement model by combining all items into a single factor (Liu et al., 2010). Our single-factor model showed a poor data fit $\left(\chi^{2}: 507.685 ; \chi^{2} / \mathrm{df}: 14.51 ; p<0.01\right.$; $\mathrm{CFI}=.726$; GFI $=0.820$; SRMR $=0.101$ and RMSEA $=0.172$ ), which confirms the non-existence of CMV.

Table 1. Fit indices for alternative measurement models

\begin{tabular}{|c|c|c|c|c|c|c|c|}
\hline Measurement Model & df & $\chi^{2}$ & $\chi^{2} / \mathrm{df}$ & CFI & GFI & SRMR & RMSEA \\
\hline Single factor model & 35 & 507.685 & 14.51 & .726 & .820 & .101 & .172 \\
\hline Two factor model & 34 & 433.130 & 12.74 & .769 & .844 & .108 & .160 \\
\hline Three factor-1 model & 32 & 371.983 & 11.62 & .803 & .858 & .058 & .153 \\
\hline Three factor-2 model & 32 & 172.261 & 5.83 & .919 & .930 & .058 & .098 \\
\hline Four factor model ${ }^{\mathrm{e}}$ & 27 & 91.216 & 3.38 & .963 & .954 & .047 & .072 \\
\hline
\end{tabular}

Note: $\mathrm{N}=457 . \mathrm{CFI}=$ comparative fit index; SRMR = standardized root mean square residual; RMSEA = root mean square error of approximation, $95 \%$ confidence interval.

${ }^{\text {a }}$ All indicators load on a single factor; ${ }^{\text {b }}$ Political will and reputation load on one factor, and political skill and network resources load on a second factor; ${ }^{c}$ Political will and reputation load on one factor, and political skill and network resources load on their respective factors; ${ }^{\mathrm{d}}$ Political will and reputation load on their respective factors, and political skill and job reputation load on one factor; ${ }^{\mathrm{e}}$ Political will, political skill, network resources and reputation load on their respective factors.

Source: own elaboration.

Moreover, we computed variance inflation factors (VIF) value to determine that there are multicollinearity issues. This value is contemplated to be a serious problem when a VIF is greater than 10, and no VIF value exceeded 10; the values ranged from 1.02 to 1.4. Hence, we see that there is no common variance error in the proposed model, and the analysis phase of the research was continued. Different fit indices were utilized to assess the goodness of fit of the model (Hu and Bentler, 1999): (a) v2/df, (b) the Standardized Root Mean Square Residual (SRMR), (c) the Root Mean Square Error of Approximation (RMSEA), and (d) the Comparative Fit Index (CFI). In this study, a model was considered to have a good fit if all the path coefficients were significant at the level of 0.05, v2/df was below 5, SRMR was below 0.08, RMSEA was below 0.08, and CFI and GFI were 0.90 or more (Bryne, 2001). 


\section{Results}

The analysis of confirmatory factor analysis (CFA) was implemented to state the separateness of different constructs used in the research. The results showed that the four-factor model fitted the data $\left(\chi^{2}: 91.216 ; \chi^{2} / \mathrm{df}: 3.38 ; \mathrm{p}<0.01\right.$; CFI: 0.96; GFI: 0.95; SRMR: 0.047; RMSEA: 0.072), and we argued that all four variables - political will, political skill, network resources, and reputation - were different from each other in Table 1. Moreover, no variables with factor load less than 0.50 were excluded from the analysis, and all the variables were included in the analysis. All the factor loadings were significant for the indicators on latent variables $(p<0.001)$, indicating that the indicators well represented all latent structures. Factor loadings ranged from $0.69-0.92$ in political will, $0.34-0.65$ in political skill, $0.55-0.87$ in network resources, and $0.67-0.86$ which are higher than the 0.60 cut-off limit, and it was seen that the internal consistency values of each variable value were at proper levels. Moreover, the composite reliability (CR) of 0.86 in reputation from all latent constructs surpassed the 0.7 threshold limit ranging from 0.69 to 0.83 . All constructs' average variance extracted (AVE) scores range from 0.50 to 0.71 , which are higher than the 0.5 thresholds. Furthermore, the indicators related to subdimensions of the main structures were reduced to a single dimension, and Cronbach's alpha AVE and CR values are shown in the table. Moreover, the R2 value of the endogenous constructs ranged from 0.30 to 0.85 and surpassed the recommended minimum value of 0.1 , which shows that the model is suitable for testing the hypotheses (Sanz-Valle and Jimenez-Jimenez, 2018). After that, we used the approach proposed by Fornell and Larcker (1981) to evaluate discriminant validity.

Table 2. Properties and correlations of the constructs

\begin{tabular}{|c|c|c|c|c|c|c|c|c|}
\hline & $\begin{array}{l}\text { Factor } \\
\text { Loadings }\end{array}$ & Mean & SD & AVE & 1 & 2 & 3 & 4 \\
\hline 1. PW & $0.69-0.92$ & 3.94 & 1.06 & 0.66 & - & & & \\
\hline 2. PS & $0.34-0.65$ & 4.94 & 0.59 & 0.50 & $0.42 * *$ & - & & \\
\hline 3. NET & $0.55-0.87$ & 4.69 & 0.90 & 0.54 & $0.35^{\star *}$ & $0.63 * *$ & - & \\
\hline 4. REP & $0.67-0.86$ & 5.17 & 0.62 & 0.71 & $0.23^{* *}$ & $0.70 * *$ & $0.61^{* *}$ & - \\
\hline Cronbach's $\alpha$ & & & & & 0.89 & 0.88 & 0.84 & 0.90 \\
\hline $\begin{array}{l}\text { Composite } \\
\text { Reliability }\end{array}$ & & & & & 0.79 & 0.79 & 0.69 & 0.83 \\
\hline
\end{tabular}

Note: PW - Political will; PS - Political skill; Net - Network resources; REP - reputation. *Correlation is significant at 0.001 (2-tailed). Source: own elaboration. 
These authors suggest that the square root of the average variance extracted (AVE) of each construct is greater than the correlation among the constructs (see Table 2). All variables were found to have discriminant validity in the study.

Figure 1. The final structural model $(\mathrm{N}=457)$

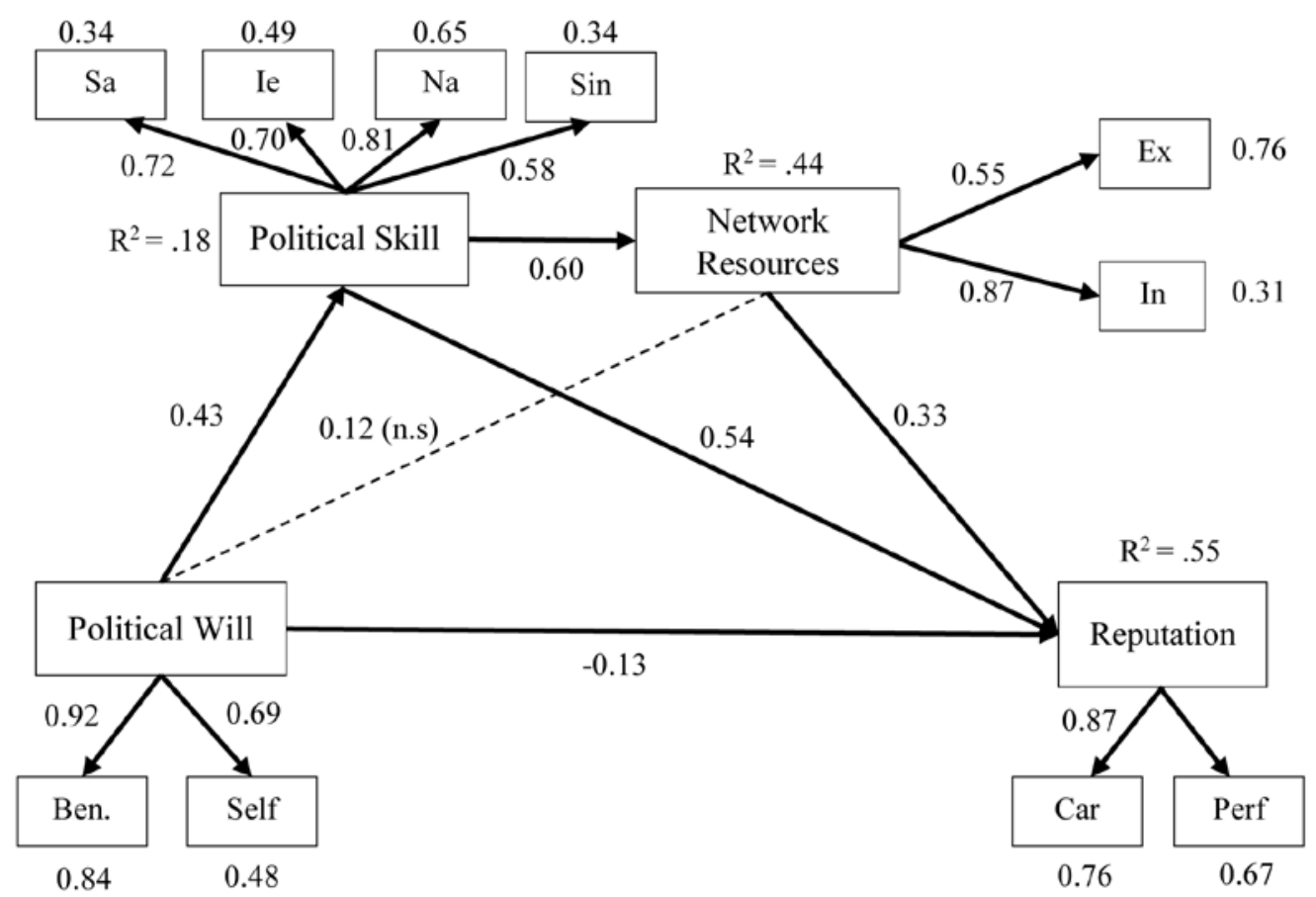

Note: Factor loadings are standardized $(p<0.05)$. Ben - benevolent; Self - self-interest; Sa - social astuteness; le - interpersonal effect; Sin - sincerity; En - expressive network resource; In - instrumental network resource; Car - career; Perf - performance. Total effect $(\mathrm{PW} \rightarrow \mathrm{NET})=0.29 *(.07)$.

Source: own elaboration.

Consequently, the research model has suitable discriminant validity, internal consistency and reliability, and convergent validity. As indicated in Table 1, political will is positively related to political skill $(r=0.42, p<0.001)$, network resources $(r=0.35, p<0.001)$, and reputation $(\mathrm{r}=0.23, \mathrm{p}<0.001)$. Moreover, political skill is positively related to network resources $(\mathrm{r}=0.63, \mathrm{p}<0.001)$ and reputation $(\mathrm{r}=0.70, \mathrm{p}<0.001)$. Lastly, network resources are positively related to reputation $(\mathrm{r}=0.71, \mathrm{p}<0.001)$. These results are consistent and provide a starting point for testing our hypothesis. To test the hypotheses of this study, we carried out structural equation model analysis to specify whether the theoretical relationships determined at the conceptualization stage were supported by the data (Diamantopoulos and Siguaw, 2000). The SEM analysis demonstrates the predominance of Model $\left(\chi^{2}: 91.216 ; \chi^{2} / \mathrm{df}: 3.38 ; p<0.01\right.$; CFI: 0.96; GFI: 0.95; 
SRMR: 0.047; RMSEA: 0.072) in which political will was received as an exogenous variable and predicted political skill (directly), network resources (directly and indirectly), and reputation (directly and indirectly). The acceptable ratio of $\chi^{2} / \mathrm{df}$ should be less than 3 (Bentler, 1989; Wheaton et al., 1977); the value of GFI and CFI exceed 0.90 (Bryne, 2001); RMSEA ratio should be less than 0.10 (Henry and Stone, 1994) and SRMR should be less than 0.1. The proposed model is an adequate fit. As Table 3 indicates, the results support the related hypotheses.

Consequently, the research model has suitable discriminant validity, internal consistency and reliability, and convergent validity. As indicated in Table 1, political will is positively related to political skill $(r=0.42, p<0.001)$, network resources $(r=0.35$, $\mathrm{p}<0.001)$, and reputation $(\mathrm{r}=0.23, \mathrm{p}<0.001)$. Moreover, political skill is positively related to network resources $(\mathrm{r}=0.63, \mathrm{p}<0.001)$ and reputation $(\mathrm{r}=0.70, \mathrm{p}<0.001)$. Lastly, network resources are positively related to reputation $(\mathrm{r}=0.71, \mathrm{p}<0.001)$. These results are consistent and provide a starting point for testing our hypothesis. To test the hypotheses of this study, we carried out structural equation model analysis to specify whether the theoretical relationships determined at the conceptualization stage were supported by the data (Diamantopoulos and Siguaw, 2000). The SEM analysis demonstrates the predominance of $\operatorname{Model}\left(\chi^{2}: 91.216 ; \chi^{2} / \mathrm{df}: 3.38 ; \mathrm{p}<0.01\right.$; CFI: 0.96; GFI: 0.95; SRMR: 0.047; RMSEA: 0.072) in which political will was received as an exogenous variable and predicted political skill (directly), network resources (directly and indirectly), and reputation (directly and indirectly). The acceptable ratio of $\chi^{2} / \mathrm{df}$ should be less than 3 (Bentler, 1989; Wheaton et al., 1977); the value of GFI and CFI exceed 0.90 (Bryne, 2001); RMSEA ratio should be less than 0.10 (Henry and Stone, 1994) and SRMR should be less than 0.1 . The proposed model is an adequate fit. As Table 3 indicates, the results support the related hypotheses.

Table 3 indicates that the results support the related hypotheses. To investigate whether both political skill and network resources mediate the effects of political will and reputation, we followed Preacher and Hayes (2008) and Sobel's test (1982) and estimated the direct and indirect effects of the independent variable and mediator variable on dependent variable using the bootstrapping procedure (via AMOS with 5,000 samples; Efron and Tibshirani, 1993; Mooney and Duval, 1993), addressing some weakness coupled with the Sobel's test (Preacher and Hayes, 2008; Shrout and Bolger, 2002).

Five thousand bootstraps were generated based on the 457 cases with the symmetric and $95 \%$ bias-corrected (BC) bootstrap confidence interval (CI) in Table 3. The bootstrapping result presented that path coefficient of political will-political skill-reputation is statistically significant (standardized $=0.18$, with a 95 percent BC bootstrap CI of 
0.082-0.298, S.E. $=0.040, p=0.000, z=5.14$, S.E $=.03, p<0.001$ ). The bootstrapping results also confirmed that the indirect effect of political skill-network resources-reputation is statistically significant (standardized $=-0.061$, with a $95 \%$ BC bootstrap CI of $-0.124-0.06$, S.E. $=0.03, p=0.018, z=3.64$, S.E $=.06, p<0.001$ ). Therefore, $\mathrm{H}_{1}$ and $\mathrm{H}_{2}$ hypotheses were supported. The bootstrapping result showed that path coefficient of political will-political skill-network resources reputation is statistically significant (standardized $=0.064$, with a 95 percent BC bootstrap CI of 0.029-0.111, S.E. $=0.02$, $\mathrm{p}=0.000, \mathrm{z}=3.12$, S.E $=.0, \mathrm{p}<0.001$ ), and $\mathrm{H}_{3}$ hypothesis was corrected in the analysis result. As shown in Table 3, the indirect effects of political will on reputation through political skill and network resources were significant. Moreover, all mediation analyses were found to have partially mediation effects in the analysis results.

Table 3. Path coefficients and indirect effects for mediation models

\begin{tabular}{|c|c|c|c|c|c|c|}
\hline & \multicolumn{3}{|c|}{ Path Coefficients } & \multicolumn{3}{|c|}{ Indirect Effects } \\
\hline & $\begin{array}{c}\text { to } \\
\text { REP }\end{array}$ & $\begin{array}{l}\text { to } \\
\text { PS }\end{array}$ & $\begin{array}{c}\text { to } \\
\text { NET }\end{array}$ & Estimate & $\begin{array}{c}\text { Symmetric } \\
\% 95 \\
\text { Confidence } \\
\text { Interval }\end{array}$ & $\begin{array}{c}\text { Bias- } \\
\text { Corrected } \\
\text { Bootstrap } \\
\text { Confidence } \\
\text { interval }\end{array}$ \\
\hline PW & $-.128 *(.06)$ & $.428 * * *(.06)$ & $.122 *(.06)$ & & & \\
\hline PS & $.539 * * *(.07)$ & & $.601 * *(.07)$ & & & \\
\hline NET & $.325^{* * *}(.08)$ & & & & & \\
\hline Total & & & & $.181(.04)$ & $.139-.284$ & $.143-.289$ \\
\hline $\mathrm{PW} \rightarrow \mathrm{PS} \rightarrow \mathrm{Rep}$ & & & & $.178^{* * *}(.04)$ & $.102-.261$ & $.108-.266$ \\
\hline $\mathrm{PS} \rightarrow \mathrm{Net} \rightarrow \mathrm{Rep}$ & & & & $-.061 *(.03)$ & $-.124-.06$ & $-.130-.010$ \\
\hline $\begin{array}{l}\mathrm{PW} \rightarrow \mathrm{PS} \rightarrow \mathrm{Net} \\
\rightarrow \operatorname{Rep}\end{array}$ & & & & $.064 * * *(.02)$ & $.029-.111$ & $.032-.118$ \\
\hline
\end{tabular}

Note: Adapted from Hayes, A.F., Preacher, K.J. and Myers, T.A. (in press). Mediation and the Estimation of Indirect Effects in Political Communication Research. In: E. P. Bucy and R. L. Holbert (eds.), Sourcebook for Political Communication Research: Methods, Measures, and Analytical Techniques. New York, NY: Routledge, 2020. N = 457. Bootstrap confidence intervals were constructed using 5000 resamples. Total effect (PW $\rightarrow$ REP $)=0.19^{*}(.06)$, Standard error in parentheses. ${ }^{*} p<0,05,{ }^{* *} p<0,01,{ }^{* * *} p<0,001$.

Source: own elaboration. 


\section{Discussion}

In the last few decades, there was a significant increase in the work on the political view of organizations (Blickle et al., 2011). For a long time defining organizations as political arenas, scholars discuss what role individuals' characteristics (e.g. motivation and ability) play in their social capital (Zhang et al., 2009; Treadway et al., 2010; Wei et al., 2010; Wei et al., 2012; Treadway et al., 2012; Bolender et al., 2015; Yang et al., 2019) and positive reputation (Blass and Ferris, 2007; Laird et al., 2009; Hall et al., 2009; Blickle et al., 2011; Zinko, 2013; Zinko et al., 2012; Laird et al., 2013; Ferris et al., 2014; Zinko and Rubin, 2015). While the theory of political influence proposed by Ferris et al. $(1991 ; 2007)$ mostly focuses on political skill research in the literature, the political will - the twin of political skill - is researched in the literature only to a limited extent (Kapoutsis et al., 2017). Although the development of personal reputation is the essential consequence of political will in organizations, intermediate linkages between political will and personal reputation have not been considered to date. Based on political influence, social network, and signaling theory, the present study investigated the relationships between political will, political skill, network resources, and personal reputation. Survey results from the sample of sales executives in Turkey showed that (1) political skill mediated the relationship between political will and network resources, (2) network resources mediated the relationship between political skill and personal reputation, and (3) political skill and network resources sequentially mediated the relationship between political will and personal reputation.

\section{Theoretical and Practical Contribution}

This study presents various contributions to the literature. Firstly, Mintzberg (1983) emphasizes the value of both political skill and political will, and he does this even though political skill is generally dominant in the literature. Political skill is expressed as a competent fulfillment of political behavior, but there is a significant deficiency in the political will that is on the motivational side of this behavior (Doldor et al., 2013). Some studies state that even people with political skills do not achieve the desired results unless they exhibit political behavior (Shi et al., 2013). However, political skill alone is insufficient to perform political behavior (Mintzberg, 1983). Political skill without political will is immobile and will not work. Still, political skill research has been developed for a long time without considering the motivation side (Kapoutsis et al., 2017). The literature analysis reveals that while political skill is considered as the interaction term of political will (Bentley et al., 2015; Harris et al., 2016), others state that political skill will predict political will (Kimura, 2015). Kapoutsis et al. (2017) reveal a significant relationship between political will and political skill, and 
the results of our research confirm the existence of this relationship. Besides, we contribute to the literature in terms of expressing political will as the antecedent of political skill and the missing part in the theory of political influence.

Secondly, social network investigations are interested in the reasons for people's networking, the results and processes that affect networks (Yang et al., 2019; Carpenter et al., 2012; Borgatti and Foster, 2003), and numerous researchers in the literature propose to investigate the political characteristics of social networks (Zhang et al., 2009; Brass and Krackhardt, 2012; Wie et al., 2012; Yang et al., 2019). Therefore, it is necessary to examine more at the intersection of politics and social networks as there are structural indicators of the potential impact of the individual in an organization (Ferris et al., 2019). To date, most research in the organizational politics literature has focused on the political skill-social network relationship (e.g. Wei et al., 2010; Wei et al., 2012; Bolendar et al., 2015; Fang et al., 2015; Li, Sun and Cheng, 2017). Previous studies focus on factors such as individual and demographic characteristics (Galaskiewicz and Shatin, 1981; Ibarra, 1993; Mehra et al., 2001; Bozioneles, 2003). Wei et al. $(2010,2012)$ reveal that political skill - accepted as an individual characteristic - has a positive relationship with network resources. The findings of our study also support related research. Although many studies reveal the existence of the social network relationship of political skill, political will as a motivational factor rarely appears in academic studies (e.g. Yang et al., 2019). Therefore, the motivation used to help configuration network resources has not been adequately explained (Zhang et al., 2009; Wei et al., 2012). Besides, it is political will that pushes individuals to invest in political skills for them to achieve their goals (Kapoutsis et al., 2017). Without political will, this skill will remain immobile. Thus, the person who influences will fail. Therefore, the political characteristics that individuals should possess in organizations are essential for obtaining and developing social networks. People who see rewards, career, and advancement opportunities in an organization and who are motivated to achieve them will obtain both expressive and instrumental social networks in the organization by using their political skill. Hence, this is the first study to demonstrate the mediating effect of political skill in the relationship between political will and network resources.

Thirdly, Lin (1999) states that various formal and informal relationship ties provide individuals with essential knowledge, power, and reputation. The relationship of political skill with both network resources (Wei et al., 2012; 2010) and personal reputation (Zinko et al., 2007; 2016; Laird et al., 2012) is frequently found in the literature. Political skills facilitate the development of network resources, which provides critical social resources and information to benefit individuals' careers and performances (Wei et al., 2012). The relationship of political skill with both network resources and 
personal reputation is frequently found in the literature. Network resources provide managers with valuable resources and information. In this way, people in executive positions increase their reputation by knowing which style is the right influencing behavior for whom. Therefore, career success depends on the ability of these individuals to use resources and information to their advantage. Besides, these managers will easily reach their individual/organizational goals thanks to the social capital they acquire, by using their political skills and the positive signals they send to both their superiors and subordinates. Our study provides evidence that political skill is an essential contextual factor in the process of network use. Therefore, using political skills while obtaining and expanding network resources is critical to the success of one's performance and career (Wei et al., 2012).

Another significant contribution of our research is vital for revealing the sequential mediation role of political skill and network resources in the relationship between political will and personal reputation by using theories of political influence, social capital, and signaling. Doldor et al. (2013) find that participation in politics is associated with reputation capital risk. Hochwarter et al. (2006) state that as the individuals' willingness to participate in politics increases, they are increasingly moving away from their job. In particular, individuals with high political will can push the conditions more to get what they want. In this case, it is not considered well by the person's surroundings and may face a significant risk in his/her reputation. Managers, who think that they can achieve positive performance results, progress opportunities, or awards in their organizations will act more actively for their motivations. Those who are motivated use their political skills to achieve such positive outcomes. Therefore, thanks to political will and political skill, they will expand their social capital further, will have the knowledge and resources to benefit them, and will convey positive signals to their environment by using appropriate influencing tactics. Besides, politically talented individuals are geared to establish strong and positive relationships with their superiors so as to achieve rewards typically associated with positive personal reputation (Blickle et al., 2011). Thus, such people can further improve their reputation (Perrewe et al., 2007). As a result of their political skills, they will both acquire relevant information from their networks and have strategic resources. They will gain positive reputation in their environment thanks to the signals they receive. Therefore, further analysis of the development of political skill and political will is important for the understanding of various organizational issues such as socialization, leadership development, and strategic management (Kimura, 2015).

One implication of this study is that people with high political will and political skill reach their network resources more easily, and their personal reputation is higher. In 
this way, such people benefit the organization in terms of the sustainability of business results and reputation. This study implies that training sessions should be organized in organizations to determine people with these features and improve them. Another implication of the study is that potential employees with these features should be prioritized while determining the candidates to be interviewed, and this process can be included in the employment procedure.

\section{Limitations and Future Research}

One major limitation of the current study is that it was performed with sales professionals. This reveals the possibility that the relationships between political will, political skill, network resources, and personal reputation may appear stronger than they would if the study was performed on people of other professions. The possible stronger relationship might be due to the nature of sales. Another study might include other professions as well. While this study included salespeople as members of an enterprising job following Holland's theory, the new study might include people with jobs from other categories of Holland's framework so that they would obtain results from a diverse pool of data.

Moreover, there are limitations to our study regarding gender issues such as gender barriers and gender inequality in business life, and their effects on the variables of this study could not be measured and indicated. The effect of the reputation of employees, managers, or the whole organization on network resources was not measured either. This effect should also be measured so that the reciprocity of the two variables is ensured. When the literature is examined, there are many reputable studies in which the reputation scale is self-assessed (Liu et al., 2007; Hochworter et al., 2007; Blickle et al., 2011). However, future studies can have the reputation of a person be evaluated by subordinates or superiors.

This study can be fruitful in terms of new research directions. A possible study might include a bilateral measurement of the effect of reputation on network resources, and vice versa. Another study might include the investigation of the variables of this study with professionals, excluding sales professionals. Different professions might reveal different results. The variables of political will, political skill, and reputation were evaluated by the employees themselves in this study. However, other studies might also include 360-degree evaluations of peers and managers, thus revealing results from a wider perspective of comparisons. In another study, these variables might be measured by comparing them with business results and the timing of employee promotions. Another interesting research direction might regard the COVID-19 pandemic. 
As we know, the online work of people has dramatically increased due to the pandemic. Concordantly, online reputation and online network resources gained in importance. Thus, the effect of political will and political skill on online reputation and online network resources might be another interesting research topic.

\section{Conclusion}

Drawing on theories of political influence, social networks, and signaling, this study examined the roles that political will plays in personal development and reputation. Our findings confirm the antecedent role of political will and political skill in establishing and utilizing network resources, which in turn influence personal reputation. Therefore, this study contributes to the literature by revealing the mechanism that underlies the relationship between political will and personal reputation. Moreover, our study also introduces personal reputation in organizations to our understanding of the boundary condition under which political skill and network resources are linked.

\section{References}

Ahearn, K.K., Ferris, G.R., Hochwarter, W.A., Douglas, C., and Ammeter, A.P. (2004). Leader political skill and team performance. Journal of Management, 30(3), 309-327.

https://doi.org/10.1016/j.jm.2003.01.004.

Ammeter, A.P., Douglas, C., Gardner, W.L., Hochwater, W.A., and Ferris, G.R. (2002). Toward a political theory of leadership. The Leadership Quarterly, 13, 751-756. https://doi.org/10.1016/S1048-9843(02)00157-1.

Andrews, M.C., Kacmar, K.M. and Valle, M. (2016). Surface acting as a mediator between personality and attitudes. Journal of Managerial Psychology, 31(8), 1265-1279. https://doi.org/10.1108/JMP-11-2015-0414.

Bentler, P.M. (1989). EQS Structural Equations Program Manual. BMDP, Los Angeles, CA.

Bentley, J.R., Breland, J.W., Xu, N., Campion, E.D., and Treadway, D.C. (2015). The political skill and will of expatriates in acculturating to the politics of an organization in a new culture. International Journal of Intercultural Relations, 49, 343-353. https://doi.org/10.1016/j.ijintrel.2015.06.002.

Beyerlein, K. and Hipp, J. (2006). From pews to participation: the effect of congregation activity and context on bridging civic engagement. Social Problems, 53(1), 97-117. https://doi.org/10.1525/sp.2006.53.1.97.

Blass, F.R. and Ferris, G.R. (2007). Leader reputation: The role of mentoring, political skill, contextual learning and adaptation. Human Resource Management, 46, 5-19. https://doi.org/10.1002/hrm.20142.

Blickle, G., Kramer, J., Zettler, I., Momm, T., Summers, J.K., Munyon, T.P. and Ferris, G.R. (2009). Job demands as a moderator of the political skill-job performance relationship. Career Development International, 14(4), 333-350, https://doi.org/10.1108/13620430910979835. 
Blickle, G., John, J., Ferris, G.R., Momm, T., Liu, Y., Haag, R., Meyer, G., Weber, K. and Oerder, K. (2012). Fit of political skill to the work context: a two-study investigation. Applied Psychology, 61, 295-322. https://doi.org/10.1111/j.1464-0597.2011.00469.x.

Blickle, G., Schneider, P.B., Liu, Y. and Ferris, G.R. (2011). A predictive investigation of reputation as mediator of the political-skill/career-success relationship. Journal of Applied Social Psychology, 41, 3026-3048. https://doi.org/10.1111/j.1559-1816.2011.00862.x.

Blickle, G., Schütte, N., and Wihler, A. (2018). Political will, work values, and objective career success: A novel approach - The Trait-Reputation-Identity Model. Journal of Vocational Behavior, 107, 42-56. https://doi.org/10.1016/j.jvb.2018.03.002.

Blombäck, A. and Botero, I.C. (2013). "Reputational capital in family firms: understanding uniqueness from the stakeholder's point of view”. In: K.X. Smyrnios, P.Z. Poutziouris, and S. Goel (eds.), Handbook of Research on Family Business, 2nd ed., Northampton: Edward Elgar Publishing, MA, 677-693.

Bolander, W., Satornino, C.B., Hughes, D.E., and Ferris, G.R. (2015). Social networks within sales organizations: their development and importance for salesperson performance. Journal of Marketing, 79(6), 1-16. https://doi.org/10.1509/jm.14.0444.

Borgatti, S.P. and Foster, P.C. (2003). The network paradigm in organizational research: A review and typology. Journal of Management, 29(6), 991-1013. https://doi.org/10.1016/S0149-2063(03)00087-4.

Bozioneles, N. (2003). Intra-organizational network resources: Relation to career success and personality. The International Journal of Organizational Analysis, 11(1), 41-66. https://doi.org/10.1108/eb028962.

Bozioneles, N. and Wang, L. (2006). The relationship of mentoring and network resources with career success in the Chinese organizational environment. The International Journal of Human Resource Management, 17(9), 1531-1546. https://doi.org/10.1080/09585190600878345.

Bozionelos, N. (2015). Social capital and careers: Indisputable evidence and note for caution. In: A. De Vos and B.I.J.M. Van der Heijden (eds.), Handbook of Research on Sustainable Careers, 67-82. Cheltenham, UK: Edward Elgar.

Brass, D.J. (2001). Social capital and organizational leadership. In: S.J. Zaccaro and R.J. Klimoski (eds.), The nature of organizational leadership. San Francisco: Jossey-Bass.

Brass, D.J., and Krackhardt, D. (2012). Power, politics, and social networks in organizations. In: G.R. Ferris and D.C. Treadway (eds.), In politics in organizations: theory and research considerations, 355-375. New York, NY: Routledge/Taylor and Francis.

Breland, J.W., Treadway, D.C., Duke, A.B., and Adams, G.L. (2007). The interactive effect of leader-member exchange and political skill on subjective career success. Journal of Leadership and Organizational Studies, 13(3), 1-14. https://doi.org/10.1177/10717919070130030101.

Brislin, R.W. (1986). A culture general assimilator: Preparation for various types of sojourns. International Journal of Intercultural Relations, 10(2), 215-234. https://doi.org/10.1016/0147-1767(86)90007-6.

Brouer, R.L., Douglas, C., Treadway, D.C., and Ferris, G.R. (2013). Leader political skill, relationship quality, and leadership effectiveness: a two-study model test and constructive replication. Journal of Leadership and Organizational Studies, 20(2), 185-198, https://doi.org/10.1177/1548051812460099.

Burt, R.S. (1992). Structural holes: The social structure of competition. Cambridge, MA: Harvard University Press.

Burt, R.S. (1997). The contingent value of social capital. Administrative Science Quarterly, 42(2), 339-365. https://doi.org/10.2307/2393923.

Burt, R.S. (2005). Brokerage and closure. Oxford, UK: Oxford University Press.

Byrne, B.M. (2001). Structural equation modeling with Amos: Basic concepts, applications, and programming. Mahwah, NJ: Erlbaum. 
Cannings, K., and Montmarquette, C. (1991). Managerial momentum: a simultaneous model of the career progress of male and female managers. ILR Review, 44(2), 212-228. https://doi.org/10.1177/001979399104400202.

Carpenter, M.A., Li, M., and Jiang, H. (2012). Social network research in organizational contexts: a systematic review of methodological issues and choices. Journal of Management, 38(4), 1328-1361. https://doi.org/10.1177/0149206312440119.

Coleman, J.S. (1988). Social capital in the creation of human capital. American Journal of Sociology, 94, 95-120. https://doi.org/10.1086/228943.

Coombs, W.T., and Holladay, S.J. (2002). Helping crisis managers protect reputational assets: initial tests of the situational crisis communication theory. Management Communication Quarterly, 16(2), 165-186. https://doi.org/10.1177/089331802237233.

Diamantopoulos, A. and Siguaw, J.A. (2000). Introducing LISREL, Thousand Oaks, CA: Sage.

Doldor, E., Anderson, D. and Vinnicombe, S. (2013). Refining the concept of political will. British Journal of Management, 24, 414-427. https://doi.org/10.1111/j.1467-8551.2012.00812.x.

Drory, A. (1993). Perceived political climate and job attitudes. Organization Studies, 14(1), 59-71. https://doi.org/10.1177/017084069301400105.

Eby, L.T. (1997). Alternative forms of mentoring in changing organizational environments: A conceptual extension of the mentoring literature. Journal of Vocational Behavior, 51: 125-144. https://doi.org/10.1006/jvbe.1997.1594.

Edelman, L.F., Bresnen, M., Newell, S., Scarbrough, H., and Swan, J. (2004). The benefits and pitfalls of social capital: Empirical evidence from two organizations in the United Kingdom. British Journal of Management, 15, 59-69. https://doi.org/10.1111/j.1467-8551.2004.00400.x.

Efron, B., and Tibshirani, R.Ž. (1993). An Introduction to the Bootstrap. New York: Chapman and Hall.

Ellen, B.P., Ferris, G.R., and Buckley, M.R. (2013). Leader political support: Reconsidering leader political behavior. The Leadership Quarterly, 24(6), 842-857. https://doi.org/10.1016/j.leaqua.2013.10.007.

Fang, R., Chi, L., Chen, M. and Baron, R.A. (2015), Bringing political skill into social networks: findings from a field study of entrepreneurs. Journal of Management Studies, 52: 175-212. https://doi.org/10.1111/joms.12107.

Ferris, G.R., Harris, J.N., Russell, Z.A., Ellen, B. P. III, Martinez, A.D. and Blass, F.R. (2014). The role of reputation in the organizational sciences: a multi-level review, construct assessment, and research directions. In: M.R. Buckley, A.R. Wheeler, J.R.B. Halbesleben (eds.), Research in Personnel and Human Resources Management, 32, 241-303.

Ferris, G.R., Blass, F.R., Douglas, C., Kolodinsky, R.W., and Treadway, D.C. (2003). Personal reputation in organizations. In: J. Greenberg (ed.), Organizational behavior: The state of the science. Lawrence Erlbaum Associates Publishers.

Ferris, G.R., Blickle, G., Schneider, P.B., Kramer, J., Zettler, I., Solga, J., Meurs, J.A. (2008). Political skill construct and criterion-related validation: A two-study investigation. Journal of Managerial Psychology, 23, 744-771. https://doi.org/10.1108/02683940810896321.

Ferris, G.R., Kolodinsky, R.W., Hochwater, W.A. and Frink, D.D. (2001). Conceputalization, measurement, and validation of the political skill construct. Paper presented at the Academy of Management, 61st National Meeting, Washington, DC.

Ferris, G.R., Liden, R.C., Munyon, T.P., Summers, J.K., Basik, K.J., and Buckley, M.R. (2009). Relationships at work: Toward a multidimensional conceptualization of dyadic work relationships. Journal of Management, 35(6), 1379-1403, https://doi.org/10.1177/0149206309344741. 
Ferris, G.R., Perrewé, P.L., Anthony, W.P., and Gilmore, D.C. (2000). Political skill at work. Organizational Dynamics, 28(4), 25-37.

Ferris, G.R., Treadway, D.C., Kolodinsky, R.W., Hochwarter, W.A., Kacmar, C.J., Douglas, C., and Frink, D.D. (2005). Development and Validation of the Political Skill Inventory. Journal of Management, 31(1), 126-152. https://doi.org/10.1177/0149206304271386.

Ferris, G.R., Treadway, D.C., Perrewe, P.L., Brouer, R.L., Douglas, C. and Lux, S. (2007). Political skill in organizations. Journal of Management, 33(3), 290-320. https://doi.org/10.1177/0149206307300813.

Ferris, G., Ellen, B., III, McAllister, C., and Maher, L. (2019). Reorganizing organizational politics research: A review of the literature and identification of future research directions. Annual Review of Organizational Psychology and Organizational Behavior, 6, 299-323, https://doi.org/10.1146/annurev-orgpsych-012218-015221.

Fornell, C., and Larcker, D.F. (1981). Structural Equation Models with Unobservable Variables and Measurement Error: Algebra and Statistics. Journal of Marketing Research, 18(3), 382-388. https://doi.org/10.1177/002224378101800313.

Forret, M.L., and Dougherty, T.W. (2001). Correlates of networking behavior for managerial and professional employees. Group and Organization Management, 26(3), 283-311. https://doi.org/10.1177/1059601101263004.

Forret, M.L., and Dougherty, T.W. (2004). Networking behaviors and career outcomes: differences for men and women? Journal of Organizational Behavior, 25(3), 419-437. https://doi.org/10.1002/job.253.

Galaskiewicz, J., and Shatin, D. (1981). Leadership and networking among neighborhood human service organizations. Administrative Science Quarterly, 26(3), 434-448. https://doi.org/10.2307/2392516.

Gill, A., Lapalme, M., and Séguin, M. (2014). When politics meets ethics: how political skill helps ethical leaders foster organizational citizenship behaviors. Journal of Managerial Issues, 26(3), 204-218, www.jstor.org/stable/44113637.

Granger, S., Neville, L. and Turner, N. (2020), Political knowledge at work: Conceptualization, measurement, and applications to follower proactivity. Journal of Occupational and Organizational Psychology, 93: 431-471. https:/doi:10.1111/joop.12293.

Granovetter, M. (1985). Economic action and social structure: The problem of embeddedness. American Journal of Sociology, 91(3), 481-510. https://doi.org/10.1086/228311.

Granovetter, M.S. (1973). The strength of weak ties. American Journal of Sociology, 78(6), 1360-1380. https://doi.org/10.1016/B978-0-12-442450-0.50025-0.

Hall, A.T., Zinko, R., Perryman, A.A., and Ferris, G.R. (2009). Organizational Citizenship Behavior and Reputation: Mediators in the Relationships Between Accountability and Job Performance and Satisfaction. Journal of Leadership and Organizational Studies, 15(4), 381-392. https://doi.org/10.1177/1548051809331504.

Harris, J.N., Maher, L.P., and Ferris, G.R. (2016). The roles of political skill and political will in job performance prediction: A moderated nonlinear perspective. In: E. Vigoda-Gadot and A. Drory (eds.), Handbook of organizational politics: Looking back and to the future (pp. 15-39). Cheltenham: Elgar Publishing.

Hatcher, L. (1994). A Step by Step Approach to Using the SAS System for Factor Analysis and Structural Equation Modeling. SAS Institute Inc., Cary, NC.

Henry, J. and Stone, A. (1994). Structural equation model of end user satisfaction with a computer-based medical information system. Information Resources Management Journal, 7, 21-33. https://doi.org/10.4018/irmj.1994070102. 
Higgins, M.C., and Kram, K.E. (2001). Reconceptualizing mentoring at work: A developmental network perspective. Academy of Management Review, 26(2), 264-288. https://doi.org/10.5465/amr.2001.4378023.

Hochwarter, W.A., Rosen, C.C., Jordan, S.L., Ferris, G.R., Ejaz, A., and Maher, L.P. (2020). Perceptions of Organizational Politics Research: Past, Present, and Future. Journal of Management. https://doi.org/10.1177/0149206319898506.

Hochwarter, W.A., Ferris, G.R., Zinko, R., Arnell, B. and James, M. (2007). Reputation as a moderator of the political behavior - work outcomes relationships: a two-study investigation with convergent results. Journal of Applied Psychology, 92, 567-76. https://doi.org/10.1037/0021-9010.92.2.567.

Hochwarter, W.A., Witt, L.A., Treadway, D.C., and Ferris, G.R. (2006). The interaction of social skill and organizational support on job performance. Journal of Applied Psychology, 91(2), 482-489, https://doi.org/10.1037/0021-9010.91.2.482.

Hochwarter, W.A. (2012). The positive side of organizational politics. In: G.R. Ferris and D.C. Treadway (eds.), Politics in Organizations. Theory and Research Considerations. New York, NY: Routledge.

Holland, J.L. (1973). Making Vocational Choices: A Theory of Vocational Personalities and Work Environments, 1st ed. Odessa, FL: Psychological Assessment Resources.

House, R.J. (1995). Leadership in the twenty-first century. In: A. Howard (ed.), The changing nature of work. 411-450. San Francisco: Jossey-Bass.

$\mathrm{Hu}$, L.T. and Bentler, P.M. (1999). Cutoff criteria for fit indexes in covariance structure analysis: Conventional criteria versus new alternatives. Structural Equation Modeling: a Multidisciplinary Journal, 6(1), 1-55, https://doi.org/10.1080/10705519909540118.

Huang, Y. (2020). The relationship between networking behavior and promotability: The moderating effect of political skill. Journal of Management and Organization, 26(2), 185-200. https://doi.org/10.1017/jmo.2017.53.

Ibarra, H. (1993). Personal networks of women and minorities in management: A conceptual framework. Academy of Management Review, 18(1), 56-87, https://doi.org/10.5465/amr.1993.3997507.

Inkson, K. (2004). Images of career: nine key metaphors. Journal of Vocational Behavior, 65(1), 96-111. https://doi.org/10.1016/S0001-8791(03)00053-8.

Jafari, M., Akhavan, P., and Nourizadeh, M. (2013). Classification of human resources based on measurement of tacit knowledge: An empirical study in Iran. Journal of Management Development, 32(4), 376-403. https://doi.org/10.1108/02621711311326374.

Joo, B.-K., Song, J.H., Lim, D.H., and Yoon, S.W. (2012). Team creativity: The effects of perceived learning culture, developmental feedback and team cohesion. International Journal of Training and Development, 16, 77-91. https://doi.org/10.1111/j.1468-2419.2011.00395.x.

Kalaycı, Ş. (2006). SPSS uygulamalı çok değişkenli istatistik teknikleri (Vol. 2). Asil Yayın Dağıtım.

Kaplan, D.M. (2008). Political choices: The role of political skill in occupational choice. Career Development International, 13, 46-55. https://doi.org/10.1108/13620430810849533.

Kapoutsis, I., Papalexandris, A., Treadway, D.C., and Bentley, J. (2018). Measuring political will in organizations: Theoretical construct development and empirical validation. Corrigendum. Journal of Management, 44(3), 1279-1280. https://doi.org/10.1177/0149206317745884.

Kilduff, M., and Krackhardt, D. (1994). Bringing the individual back in: A structural analysis of the internal market for reputation in organizations. Academy of Management Journal, 37(1), 87-108. https://doi.org/10.5465/256771.

Kilduff, M., and Tsai, W. 2003. Social networks and organizations. Thousand Oaks, CA: Sage.

Kimura, T. (2015). A review of political skill: Current research trend and directions for future research. International Journal of Management Reviews, 17(3), 312-332. https://doi.org/10.1111/ijmr.12041. 
Klein, K.J., Lim, B.C., Saltz, J.L., and Mayer, D.M. (2004). How do they get there? An examination of the antecedents of centrality in team networks. Academy of Management Journal, 47(6), 952-963. https://doi.org/10.5465/20159634.

Kline, R.B. (2010). Principles and practice of structural equation modeling. New York Guilford Press,.

Kolodinsky, R. W., Hochwarter, W. A., and Ferris, G. R. (2004). Nonlinearity in the relationship between political skill and work outcomes: Convergent evidence from three studies. Journal of Vocational Behavior, 65, 294-308, https://doi.org/10.1016/j.jvb.2003.08.002.

Kram, K.E. (1985). Mentoring at work. Glenview. IL: Scott Foresman.

Kranefeld, I., Blickle, G., and Meurs, J. (2020, April 30). Political Skill at Work and in Careers. Oxford Research Encyclopedia of Psychology. https://oxfordre.com/psychology/view/10.1093/acrefore/9780190236557.001.0001/acrefore 9780190236557-e-747 (26.05.2020).

Kwon, S.W., and Adler, P.S. (2014). Social capital: Maturation of a field of research. Academy of Management Review, 39, 412-422. https://doi.org/10.5465/amr.2014.0210.

Laird, M.D., Perryman, A.A., Hochwarter, W.A., Ferris, G.R., and Zinko, R. (2009). The moderating effects of personal reputation on accountability-strain relationships. Journal of Occupational Health Psychology, 14(1), 70-83. https://doi.org/10.1037/a0012567.

Laird, M.D., Zboja, J.J., Martinez, A.D. and Ferris, G.R. (2013). Performance and political skill in personal reputation assessments. Journal of Managerial Psychology, 28(6), 661-676. https://doi.org/10.1108/JPM-10-2011-0097.

Lee, S., Han, S., Cheong, M., Kim, S. L. and Yun, S. (2017). How do I get my way? A meta-analytic review of research on influence tactics, The Leadership Quarterly, 28(1), 210-228. https://doi.org/10.1016/j.leaqua.2016.11.001.

Liao, H., Liu, D., and Loi, R. (2010). Looking at both sides of the social exchange coin: A social cognitive perspective on the joint effects of relationship quality and differentiation on creativity. Academy of Management Journal, 53, 1090-1109. https://doi.org/10.5465/amj.2010.54533207.

Lin, N. (1999). Building a network theory of social capital. Connections, 22(1), 28-51.

Liu, Y., Ferris, G.R., Zinko, R., Perrewé, P.L., Weitz, B., and Xu, J. (2007). Dispositional antecedents and outcomes of political skill in organizations: A four-study investigation with convergence. Journal of Vocational Behavior, 71, 146-165. https://doi.org/10.1016/j.jvb.2007.04.003.

Lu, L.C., Chang, H.H., and Chang, A. (2015). Consumer personality and green buying intention: The mediate role of consumer ethical beliefs. Journal of Business Ethics, 127(1), 205-219. https://doi.org/10.1007/s10551-013-2024-4.

MacKinnon, D.P., Lockwood, C.M., and Williams, J. (2004). Confidence limits for the indirect effect: Distribution of the product and resampling methods. Multivariate Behavioral Research, 39(1), 99-128. https://doi.org/10.1207/s15327906mbr3901_4.

Maurer, I., Bartsch, V. and Ebers, M. (2011). The value of intra-organizational social capital: how it fosters knowledge transfer, innovation performance, and growth. Organization Studies, 32, 157-185. https://doi.org/10.1177/0170840610394301.

McAllister, C.P., Ellen, B.P., and Ferris, G.R. (2018). Social influence opportunity recognition, evaluation, and capitalization: Increased theoretical specification through political skill's dimensional dynamics. Journal of Management, 44, 1926-1952. https://doi.org/10.1177/0149206316633747.

McDaniel, M.A., and Snell, A.F. (1999). Holland's theory and occupational information. Journal of Vocational Behavior, 55(1), 74-85. https://doi.org/10.1006/jvbe.1999.1698.

Mehra, A., Kilduff, M., and Brass, D.J. (2001). The social networks of high and low self-monitors: Implications for workplace performance. Administrative Science Quarterly, 46(1), 121-146. https://doi.org/10.2307/2667127. 
Mintzberg, H. (1983). Power in and around organizations. Englewood Cliffs, NJ: Prentice-Hall..

Mintzberg, H. (1985). The organization as political arena. Journal of Management Studies, 22(2), 133-154. https://doi.org/10.1111/j.1467-6486.1985.tb00069.x.

Momm, T., Blickle, G., Liu, Y., Wihler, A., Kholin, M. and Menges, J.I. (2015). It pays to have an eye for emotions: Emotion recognition ability indirectly predicts annual income, Journal of Organizational Behaviour, 36, 147-163. https://doi.org/10.1002/job.1975.

Mooney, C.Z. and Duval, R.D. (1993). Bootstrapping: A Nonparametric Approach to Statistical Inference (Vol. 95). Newbury Park, CA: Sage Publications.

Munyon, T.P., Summers, J.S, Thompson, K.W. and Ferris, G.R. (2015). Political Skill and Work Outcomes: A Theoretical Extension, Meta-Analytic Investigation, and Agenda for the Future. Personnel Psychology, 68(1), 143-84. https://doi.org/10.1111/peps.12066.

Nunnally, J.C. (1978). Psychometric theory (2nd ed.). New York, NY: McGraw-Hill.

Oerder, K., Blickle, G. and Summers, J. (2014). How work context and age shape political skill. Journal of Managerial Psychology, 29, 582-599. https://doi.org/10.1108/JMP-01-2013-0004.

Perrewe, P.L. and Ve Nelson, D.L. (2004). The facilitative role of political skill. Organizational Dynamics, 33(4), 366-378. https://doi.org/10.1016/j.orgdyn.2004.09.004.

Perrewé, P.L., Ferris, G.R., Stoner, J.S., and Brouer, R.L. (2007). The positive role of political skill in organizations. In: D.L. Nelson and C.L. Cooper (eds.), Positive organizational behavior: Accentuating the positive at work (pp. 117-128). Thousand Oaks, CA: Sage Publications.

Pfeffer, J. (1981). Power in organizations. Marshfield, MA: Pitman.

Phillips-Jones, L. (1982). Mentors and protégés. New York, NY: Arbor House. Establishing a formalized mentoring program. Training and Development Journal, 37(2), 38-42.

Pillai, K.G., Hodgkinson, G.P., Kalyanaram, G., and Nair, S.R. (2017). The negative effects of social capital in organizations: A review and extension. International Journal of Management Reviews, 19, 97-124. https://doi.org/10.1111/ijmr.12085.

Podsakoff, P.M., MacKenzie, S.B., Lee, J., and Podsakoff, N.P. (2003). Common methods biases in behavioral research: A critical review of the literature and recommended remedies. Journal of Applied Psychology, 88, 879-903. https://doi.org/10.1037/0021-9010.88.5.879.

Portes, A. (1998). Social capital: its origins and applications in modern sociology. Annual Review of Sociology, 24, 1-24. https://doi.org/10.1146/annurev.soc.24.1.1.

Post, L.A., Raile, A.N.W. and Raile, E.D. (2010). Defining Political Will. Politics and Policy, 38, 653-676. https://doi.org/10.1111/j.1747-1346.2010.00253.x.

Preacher, K.J., and Hayes, A.F. (2008). Asymptotic and resampling strategies for assessing and comparing indirect effects in multiple mediator models. Behavior Research Methods, 40(3), 879-891. https://doi.org/10.3758/BRM.40.3.879.

Richardson, J. and Kelliher, C. (2015). Managing visibility for career sustainability: a study of remote workers. In: A. De Vos and B. Van der Heijden, Handbook of Research on Sustainable Careers, pp. 116-130. Cheltenham: Edward Elgar Publishing.

Sanz-Valle, R. and Jiménez-Jiménez, D. (2018). HRM and product innovation: does innovative work behaviour mediate that relationship? Management Decision, 56(6), 1417-1429. https://doi.org/10.1108/MD-04-2017-0404.

Schulman, M.D., and Anderson, C. (1999). The dark side of the force: A case study of restructuring and social capital1. Rural Sociology, 64(3), 351-372.

https://doi.org/10.1111/j.1549-0831.1999.tb00357.x.

Seibert, S.E., Kraimer, M.L., and Liden, R.C. (2001). A social capital theory of career success. Academy of Management Journal, 44(2), 219-237. https://doi.org/10.5465/3069452. 
Shi, J., Johnson, R.E., Liu, Y., and Wang, M. (2013). Linking subordinate political skill to supervisor dependence and reward recommendations: A moderated mediation model. Journal of Applied Psychology, 98(2), 374-384. https://doi.org/10.1037/a0031129.

Smith, A.D., Plowman, D.A., Duchon, D., and Quinn, A.M. (2009). A qualitative study of high reputation plant managers: Political skill and successful outcomes. Journal of Operations Management, 27, 428-443. https://doi.org/10.1016/j.jom.2009.01.003.

Sobel, M.E. (1982). Asymptotic confidence intervals for indirect effects in structural equation models. Sociological Methodology, 13, 290-312. https://www.jstor.org/stable/270723.

Spence, M. (1973). Job market signaling, Quarterly Journal of Economics, 87(3), 355-374. https://doi.org/10.1016/B978-0-12-214850-7.50025-5.

Staw, B.M. (1981). The escalation of commitment to a course of action. Academy of Management Review, 6, 577-587. https://doi.org/10.5465/amr.1981.4285694.

Templer, K.J. (2018). Dark personality, job performance ratings, and the role of political skill: An indication of why toxic people may get ahead at work. Personality and Individual Differences, 124, 209-214. https://doi.org/10.1016/j.paid.2017.11.030.

Thompson, J.A. (2005). Proactive Personality and Job Performance: A Social Capital Perspective. Journal of Applied Psychology, 90(5), 1011-1017. https://doi.org/10.1037/0021-9010.90.5.1011.

Treadway, D.C. (2012). Political will in organizations. In: G.R. Ferris and D.C. Treadway (eds.), Politics in organizations: Theory and research considerations. New York: Routledge/Taylor and Francis.

Treadway, D.C., Adams, G.L., Ranft, A.L., and Ferris, G.R. (2009). A meso-level conceptualization of CEO celebrity effectiveness. The Leadership Quarterly, 20(4), 554-570. https://doi.org/10.1016/j.leaqua.2009.04.008.

Treadway, D.C., Breland, J.W., Adams, G.L., Duke, A.B., and Williams, L.A. (2010). The interactive effects of political skill and future time perspective on career and community networking behavior. Social Network, 32, 138-147. https://doi.org/10.1016/j.socnet.2009.09.004.

Treadway, D.C., Campion, E.D. and Williams, L.V. (2017). Sensitivity and Adaptability in the Face of Powerlessness: The Roles of Political Will and Political Skill within the Experience of Powerlessness and its Impact on Stress-Related Outcomes, Power, Politics, and Political Skill in Job Stress. Research in Occupational Stress and Well Being, 15, Emerald Publishing Limited.

Treadway, D.C., Hochwarter, W.A., Kacmar, C.J. and Ferris, G.R. (2005), Political will, political skill, and political behavior. Journal of Organizational Behavaviour, 26, 229-245. https://doi.org/10.1002/job.310.

Tsui, A.S. (1984). A role set analysis of managerial reputation. Organizational Behavior and Human Performance, 34, 64-96. https://doi.org/10.1016/0030-5073(84)90037-0.

Turulja, L. and Bajgoric, N. (2019). Innovation, firms' performance and environmental turbulence: is there a moderator or mediator? European Journal of Innovation Management, 22(1), 213-232. https://doi.org/10.1108/EJIM-03-2018-0064.

Vigoda-Gadot, E., and Drory, A. (2016). Introduction: Back to the future of organizational politics. In: E. Vigoda-Gadot and A. Drory (eds.), Handbook of organizational politics: Looking back and to the future. Cheltenham, UK: Edward Elgar.

Wang, Z., McNally, R., and Lenihan, H. (2018). The role of social capital and culture on social decision-making constraints: A multilevel investigation. European Management Journal. https://doi.org/10.1016/j.emj.2018.04.004.

Wei, L.-Q., Liu, J., Chen, Y.-Y. and Wu, L.-Z. (2010), Political Skill, Supervisor-Subordinate Guanxi and Career Prospects in Chinese Firms. Journal of Management Studies, 47, 437-454.

https://10.1111/j.1467-6486.2009.00871.x. 
Wheaton, B., Muthen, B., Alwin, D.F., and Summers, G.F. (1977). Assessing Reliability and Stability in Panel Models. Sociological Methodology, 8(1), 84-136.

https://www.jstor.org/stable/270754.

Wright, J.P. (1979). On a Clear Ray You Can See General Motors. New York: Avon.

Yang, J., Liu, C., Wang, C., and Zhang, Q. (2019). How Gender and Political Will Affect Employees' Social Network Embeddedness. Psychological Reports. https://doi.org/10.1177/0033294119862993.

Yllmaz, C. (1999). Salesforce Cooperation: The Impact of Relational, Task, Organizational and Personal Factors, PhD Thesis, Texas Tech University.

Zellars, K.L., Perrewé, P.L., Rossi, A.M., Tepper, B.J. and Ferris, G.R. (2008). Moderating effects of political skill, perceived control, and job-related self-efficacy on the relationship between negative affectivity and physiological strain. Journal of Organizational Behaviour, 29, 549-571. https://doi.org/10.1002/job.484.

Zhai, Q., Wang, S., and Weadon, H. (2017). Thriving at work as a mediator of the relationship between workplace support and life satisfaction. Journal of Management and Organization, 1-17. https://doi.org/10.1017/jmo.2017.62.

Zhang, M., Zheng, W. and Wei, J. (2009). Sources of social capital: effects of altruistic citizenship behavior and job involvement on advice network centrality. Human Resource Development Quarterly, 20, 195-217. https://doi.org/10.1002/hrdq.20015.

Zhang, W., Johnson, T.J., Seltzer, T., and Bichard, S.L. (2009). The revolution will be networked: The influence of social networking sites on political attitudes and behavior. Social Science Computer Review, 28, 75-92. https://doi.org/10.1177/0894439309335162.

Zinko, R. (2013), Reputation, political skill, and strain. Journal of Applied Social Psychology, 43, 1750-1759. https://doi.org/10.1111/jasp.12114.

Zinko, R., and Rubin, M. (2015). Personal reputation and the organization. Journal of Management and Organization, 21(2), 217-236. https://doi.org/10.1017/jmo.2014.76.

Zinko, R., Ferris, G.R., Blass, F.R. and Dana Laird, M. (2007). Toward a Theory of Reputation in Organizations. In: J.J. Martocchio (ed.), Research in Personnel and Human Resources Management (Research in Personnel and Human Resources Management, 26), Emerald Group Publishing Limited, Bingley, 163-204. https://doi.org/10.1016/S0742-7301(07)26004-9.

Zinko, R., Ferris, G.R., Humphrey, S.E., Meyer, C.J. and Aime, F. (2012). Personal reputation in organizations: Two-study constructive replication and extension of antecedents and consequences. Journal of Occupational and Organizational Psychology, 85, 156-180. https://doi.org/10.1111/j.2044-8325.2010.02017.x.

Zinko, R., Gentry, W., Hall, A., and Grant, G. (2012). Reputational Change Among Managers. Journal of Managerial Issues, 24(1), 9-26, www.jstor.org/stable/43488120 (23.05.2020).

Zinko, R., Gentry, W.A. and Laird, M.D. (2016). A development of the dimensions of personal reputation in organizations. International Journal of Organizational Analysis, 24(4), 634-649. https://doi.org/10.1108/IJOA-04-2015-0854. 